\title{
Investigations into NIH fraud allegations end with suicide
}

\section{Washington}

AN investigation into possible scientific fraud at the National Institutes of Health (NIH) has had tragic consequences. Apparently as a result of emotional pressure caused by an inquiry that focused on a researcher's conduct in his former laboratory, Howard Eisen committed suicide on 7 February, 10 days after appearing before a panel looking into the affair

Eisen was in the Laboratory of Developmental Pharmacology at the National Institute of Child Health and Human Development (NICHD), and chief of the The NIH inquiry focuses on a paper entitled "Analysis of mammalian P450 catalytic activities by genetic engineering and expression in yeast." According to Eisen's widow Laura, a research associate in chemistry at the Uniformed Services University of the Health Sciences, most of the data for the paper were gathered by Alok Bandyopadhyay. Laura Eisen says Bandyopadhyay was hired last summer by Daniel Nebert - head of Howard Eisen's section - to work in Eisen's laboratory. According to Laura Eisen, Nebert wrote the paper, although Bandyopadhyay was first author. Howard Eisen reviewed the paper, and he was one of the authors, she says.

The paper was intended for publication in the Proceedings of the National Academy of Sciences, but certain inconsistencies in the data were detected before it was actually submitted for publication. Those discrepancies prompted a careful review section on regulation of gene expression.

of Bandyopadhyay's work at NIH. Laura Eisen says her husband performed experiments that convinced him that Bandyopadhyay had adulterated his data. She says not only was there evidence that there were serious problems with Bandyopadhyay's research, but close scrutiny subsequently turned up numerous inconsistencies in his curriculum vitae. Unfortunately, Bandyopadhyay could not be reached for comment.

Results of this preliminary scrutiny prompted the NICHD to terminate Bandyopadhyay's employment last November. NICHD director Duane Alexander says that the NIH follows specific procedures in any case of suspected fraud, both within and without NIH. So on 8 January this year deputy director Joseph E. Rall named a three member pane with the object of looking into "serious discrepancies in the paper".

The panel comprises Maxine Singer of the National Cancer Institute and two other members, one from NIH and one from outside the institutes who acts as chair. The panel held its first meeting on 28 January, when both Howard Eisen and Bandyopadhyay were expected to be interviewed. But Bandyopadhyay never arrived, and after waiting several hours the meeting broke up with no substantive ground being covered.

Howard Eisen was extremely upset by his meeting with the panel according to his widow. She says he insisted on going back to his laboratory to make certain that his checks of Bandyopadhyay's work had

\section{AAAS reviewing the situation}

\section{Chicago}

The American Association for the Advancement of Science (AAAS) boasted of a remarkable coup at its annual meeting here this week - the appointment of Dr Alan Trivelpiece as its chief executive officer to succeed Mr William Carey, who is retiring. Dr Trivelpiece has been for several years responsible at the Department of Energy for, among other things, US policy on high-energy physics. He is believed to be the chief architect of the US government's decision, announced two weeks ago, to back the project to build the Superconducting Super Collider (see page 654).

In contrast with previous years, the AAAS this year has no fierce complaint to make of the federal budget for the year ahead. Neither the present nor the putative executive officer could do other than applaud the hope that Congress will allow the doubling of the budget of the National Science Foundation (NSF) over the next five years, one of the outstanding ingredients of the administration's budget for the financial year beginning next October. But Mr Gerard Piel, chairman of the AAAS board of directors, "deplored" the NSF's recent practice of setting up universitybased research centres whose effect, he said, is to undermine the autonomy of the host universities.

The AAAS itself seems also to be going through a period of heart-searching about its future. A downbeat statement in the association's house journal, Science, which records the circumstances leading to the demise of its monthly offshoot Science 86 , also says that the future of the annual meeting is being re-assessed because of poor attendences. Unsystematic sampling of this week's sessions reveals that distinguished speakers are often as numerous as those who have come to listen. But hotels have apparently been booked for the next two years. John Maddox \section{Two British scientists share Wolf Prize Rehovot is}

Two noted British biochemists will share the $\$ \mathbf{1 0 0 , 0 0 0}$ Wolf Prize in Chemistry for 1987. They are Sir David Phillips of the University of Oxford and Professor David M. Blow of Imperial College, London, who are being honoured "for their contributions to protein $\mathrm{X}$-ray crystallography and to the elucidation of structures of enzymes and their mechanism of action".

Phillips and Blow will receive the Wolf Prize from the president of Israel, Dr

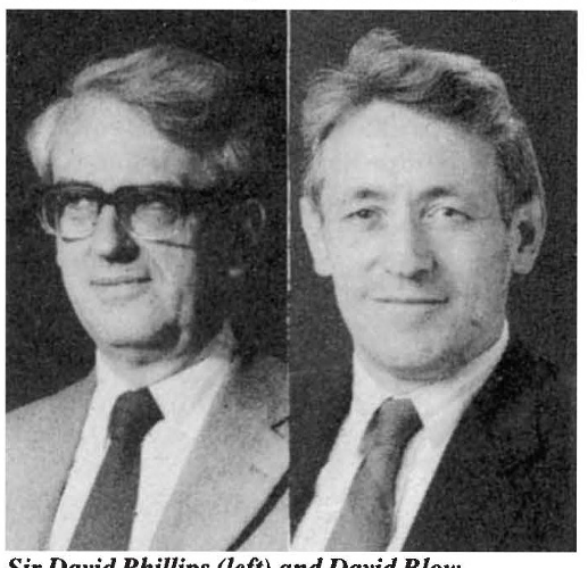

Sir David Phillips (left) and David Blow

Chaim Herzog, in ceremonies at the Knesset in Jerusalem on 31 May, when awards will also be presented for achievements in chemistry, mathematics, medicine, agriculture, physics and the arts.

Nechemia Meyers

been accurately prepared. Laura Eisen says her husband was not thinking rationally following the meeting. Upset from the start by the apparent fraud, Laura Eisen says "something snapped" after the 28 January meeting.

Friends and associates of Howard Eisen say the idea that he could have been involved in anything fraudulent is unthinkable. Jeffrey Harmon, a colleague of Laura Eisen at the Uniformed Services University of the Health Sciences who had collaborated with Howard Eisen in the past, says "there's no way Howie could have been involved in any kind of cheating".

Although he had minimal contact with Eisen, Duane Alexander describes him as "as excellent scientist". NIH has made no allegations against Eisen.

Howard Eisen came to NIH in 1971 . He was graduated from Harvard College in 1964 and Harvard Medical School in 1969. Eisen did a two-year residence at Boston City Hospital before joining NIH. His work has been primarily on glucocorticoid receptors.

$\mathrm{NIH}$ is still planning to continue its investigation into the fraud allegations.

Joseph Palca 